\title{
Entrevista com o professor Jean Bitoun*
}

Geosul - Hoje dia 19 de outubro de 2006 estamos reunidos na sala de Usos Múltiplos do Departamento de Geociências para fazer a entrevista com a professora Dora Romariz. Iniciamos a entrevista pedindo para a senhora falar um pouco sobre sua vida, onde nasceu sua família, os primeiros estudos...

Profa. Dora - Eu nasci em São Paulo, em janeiro de 1922, filha de José de Amarante Romariz e Maria da Glória de Amarante Romariz, ambos brasileiros (e cariocas). Embora sempre tivessem vivido no Rio de Janeiro, por alguns anos (de 1920 a 1929) haviam se mudado para São Paulo e, daí, eu ter nascido paulista. Tinha, portanto, sete anos quando meus pais voltaram para o Rio de Janeiro.

Éramos uma família de classe média e sempre estudei em escola pública. No Rio fiz todos os meus estudos: comecei com o primário na Escola Deodoro, na Glória. Com a mudança da família para o Andaraí, passei a freqüentar a Escola Afonso Pena.

Aos 12 anos fiz concurso e entrei para o Instituto de Educação, única instituição, na época, destinada à formação de professores primários. Eram oito anos de curso (5 de Ginásio, 1 Complementar e 2 de formação de professores).

Foi no Instituto de Educação que tive o meu primeiro emprego: monitora de geografia, quando estava no quinto ano.

Terminado o Curso Normal (como então se dizia) em dezembro de 1941, em março de 1942 fiz o vestibular para o curso de Geografia e História (era só um curso) da Faculdade Nacional de Filosofia,

\footnotetext{
* Professor da UFPE. Entrevista realizada em 31/10/2007 em Florianópolis e que contou com a participação dos professores Élson M. Pereira, Ewerton V. Machado, Sandra M. de A. Furtado e Maria Dolores Buss. Texto revisado e autorizado pelo entrevistado Xxxxxx
}

Geosul, Florianópolis, v. 23, n. 46, p , jul./dez. 2008 
Entrevista com Dora de Amarante Romariz.

Ciências e Letras da Universidade do Brasil. Quando estava quase para terminar o Curso, o Conselho Nacional de Geografia (IBGE) que iniciava suas pesquisas, precisando de geógrafos, convidou-me para lá trabalhar. Tive a satisfação de aí poder fazer toda a minha carreira até me aposentar.

Geosul - A senhora falou que o seu primeiro emprego foi de monitoria de geografia. Por quê?

Profa. Dora - Eu era boa aluna de geografia e quando o professor teve que escolher uma auxiliar, indicou meu nome.

Geosul - E como era a geografia na sua época?

Profa. Dora - O ensino da geografia, na maior parte das escolas, consistia na simples decoração: nomes de acidentes, totais de produção, etc. No Instituto, porém, tínhamos um excelente e dedicado professor (Mário da Veiga Cabral), com idéias avançadas, que se utilizava de todo o material possível: além de excelente mapoteca, instalou também um "Gabinete de Geografia" onde havia toda a espécie de material: maquetes, aparelhos diversos, até mesmo, na área, um posto meteorológico, utilizado para aulas práticas. Foi ele que me indicou para a monitoria e, durante um ano, fui contratada pela Prefeitura para esse cargo, como já disse anteriormente.

Geosul - Voltando à sua família, a senhora teve irmãos?

Profa. Dora - Tive três irmãos, mas morreram cedo, antes de eu nascer. Tive só um primo, que para mim foi um irmão de criação. Meu tio morava fora, ele ficou conosco até se formar e nos deixar. Fiquei, então, sozinha com meu pai, pois minha mãe já havia falecido. Esse foi, aliás, o motivo pelo qual não me interessei em fazer especialização no exterior. Acabei fazendo-a no meu próprio país e acho, até que lucrei bastante com isso. 
Entrevista com Dora de Amarante Romariz.

Geosul - E o seu pai trabalhava em quê?

Profa. Dora - Meu pai trabalhava no comércio e após a $2^{\mathrm{a}}$ Grande Guerra passou por momentos difíceis. Tendo recebido convite para trabalhar em São Paulo, para lá se mudou (em 1920), como já disse. Nove anos depois, com o sério problema da Depressão, ocorrida nessa época, a firma em que trabalhava fechou. Isso o levou a voltar para o Rio de Janeiro, onde permaneceu até o fim de sua vida.

Geosul - E depois de fazer o Normal, entrou para a Faculdade...

Profa. Dora - Sim. Era a Faculdade Nacional de Filosofia, Ciências e Letras da Universidade do Brasil. Depois, quando a capital do Brasil foi para Brasília, fundou-se a UnB e a Faculdade Nacional de Filosofia foi substituída pela Universidade Federal do Rio de Janeiro (UFRJ) e não existe mais "Universidade do Brasil". UnB quer dizer Universidade de Brasília.

Geosul - E como foi seu curso de graduação?

Profa. Dora - Normal: nada de especial. Lecionava pela manhã e estudava à tarde. A Faculdade era bem pequena e ocupava uma parte do Colégio Amaro Cavalcante, no Largo do Machado. Nesse prédio funcionavam os cursos de geografia-história, sociologia, filosofia, entre outros. Eram turmas bem pequenas, algumas com dois alunos apenas. A nossa turma era considerada grande, pois tinha dez alunos.

Geosul - E quais foram os seus professores?

Profa. Dora - Tivemos bons professores como, por exemplo, o Josué de Castro, na Geografia Humana; o Arthur Ramos, na Antropologia; o Vitor Leuzinger, na Geografia Física; o Hélio Viana, na História do Brasil e o Delgado de Carvalho, na História Contemporânea. Na História Antiga era o M. Antoine Bon. 
Entrevista com Dora de Amarante Romariz.

Geosul - E nessa época tinha professores estrangeiros?

Profa. Dora - Sim. O Antoine Bon., no primeiro ano e Francis Ruellan, durante todo o curso. Este assumiu a cadeira de Geografia do Brasil quando o catedrático dessa matéria foi para um estágio nos Estados Unidos. Foi a nossa sorte, pois ele dava grande ênfase aos trabalhos de campo, o que complementava muito o curso da Faculdade. Quando via, também, que tínhamos dificuldade em determinada matéria, ministrava um curso especial, ocupando até mesmo os dias de sábado (quando, normalmente, não tínhamos aulas), pois, para ele isso não era problema. Todos os que passaram pelo curso de Geografia, no período de quinze anos em que o Prof. Ruellan esteve no Brasil, devem a ele a parte principal de sua formação. Formar geógrafos era a sua principal preocupação e, por isso, não foram muitos os trabalhos que aqui escreveu: não the sobrava tempo para isso!

Tanto o Prof. Bon quanto o Prof. Ruellan ministravam suas aulas em francês, o que obrigou alguns dos alunos a irem estudar essa língua, o que foi ótimo! Apenas a Lysia e eu não tínhamos problema e procurávamos ajudar os demais. A Lysia por ter estudado em colégio francês, e eu por ter minha mãe, que tinha excelente conhecimento desse idioma, tido a feliz idéia de falar sempre comigo em francês. Assim, aprendi-o quase ao mesmo tempo que o português. Fui "bilíngüe" desde tenra idade, o que me foi de grande utilidade pela vida afora, facilitando enormemente todos os meus trabalhos.

Geosul - E quando a senhora conheceu o Prof. Dansereau?

Profa. Dora - Foi em 1945. A Faculdade de Filosofia convidou o Prof. Pierre Dansereau (de Montreal, Canadá), para dar um curso no Departamento de Geografia. Aceitando o convite solicitou, entretanto, que fosse possível participar, primeiramente, de alguns trabalhos de campo, para que pudesse aprender o português. Assim foi feito de 1945 a meados de 1946 quando, então, deu o curso em português! 
Entrevista com Dora de Amarante Romariz.

Como nós sentíamos falta da Biogeografia, pois no curso da Faculdade ela não era ensinada, o Conselho de Geografia indicou dois geógrafos para fazerem o curso: o Edgar Kuhlmann e eu. Terminadas as aulas fomos mantidos à disposição do Prof. Dansereau para sermos treinados por ele em trabalhos de campo, durante o resto do tempo que ele aqui ficou.

Foi ótimo para ambos os lados: nós aprendemos a conhecer melhor o nosso próprio ambiente e ele teve a oportunidade de realizar observações em um país completamente diferente do seu. Não podemos deixar de fazer referência à grande amizade que nos uniu e que persiste até hoje.

Geosul - E depois disso vocês trabalharam na carta da UNESCO? Profa. Dora - Não. A carta da Unesco não tem nada a ver com isso. Foi um trabalho do qual participei depois de aposentada e, portanto, sem nenhuma relação com as minhas atribuições no Conselho de Geografia.

Em viagem à França, em 1971, fui a Toulouse para visitar o "Institut de la Carte International du Tapis Vegetal" (ICITV), fundado pelo Prof. Henri Gaussen e rever esse amigo. Fui recebida com muita alegria, dizendo-me ele que estava mesmo para me escrever, solicitando a minha colaboração para um trabalho que o Instituto iria realizar. A UNESCO lhes havia pedido a confecção do Mapa da Vegetação da América do Sul. Achavam que seria interessante que eu ficasse incumbida de coletar aqui, junto às diferentes fontes dos diversos países, o máximo de documentação possível e, periodicamente, fosse até lá para que, juntos, a examinássemos.

É claro que aceitei e, durante quase oito anos, fui várias vezes a Toulouse, cumprindo essa finalidade.

Editado pela UNESCO, em 1981, representou, assim, esse mapa o resultado de cerca de 10 anos de trabalhos. Além dele foi feito, também, o de clima. O ano de 1981 ficou, também, assinalado pelo falecimento do Prof. Gaussen, poucos dias após ter completado 90 anos de idade. 
Geosul - A senhora se formou em 1945, quando estava começando a se construir aquilo que veio a se chamar os anos dourados da geografia...

Profa. Dora - Eu não sei por que esta história de anos dourados: nunca entendi! Dourados? E a gente vivia com o pé na lama! Não tinha estrada, nada funcionava. Para fazer uma ligação telefônica do Rio para São Paulo demorava oito horas...!

Geosul - Mas é nesta época que o IBGE vai se constituir não só para o Brasil, mas até para o mundo como uma referência.

Profa. Dora - Sim claro, por este aspecto estou de acordo. Foi, inclusive nessa época (1952) que se realizou o XVII Congresso Internacional de Geografia, promovido pela União Geográfica Internacional, em Washington. $\mathrm{O}$ Brasil enviou uma grande delegação (na qual fui incluída), chefiada pelo Presidente do IBGE. Muitos de seus membros, sendo sócios da AGB. Por uma questão de justiça, cabe salientar que essa presença tão grande da AGB, só foi possível graças a seu então Presidente - Prof. José Veríssimo da Costa Pereira, que se empenhou junto às diferentes Instituições para que, ao designar os respectivos representantes, dessem preferência àqueles que fossem sócios da AGB! Desse grupo, por exemplo, fez parte Victor Peluso Júnior, que vocês muito bem conhecem!

No final do congresso de Washington, por votação, ficou decidido que o próximo congresso, quatro anos depois, seria realizado no Brasil, em 1956. Isto nos deixou bastante preocupados pois, as condições de infra-estrutura existentes na época no Brasil, deixavam muito a desejar.

De início, o Departamento de Geografia da Faculdade Nacional de Filosofia, dirigido pelo Prof. Hilgard Sternberg, então um dos Vice-Presidentes da UGI, tentou incumbir-se de organizar o evento. Deu-se conta, porém, desde logo, que sem a colaboração do Conselho de Geografia a tarefa seria inviável. Assim, durante os três anos que antecederam o congresso, praticamente todos os 
Entrevista com Dora de Amarante Romariz.

geógrafos, muitos funcionários administrativos, além do Serviço Gráfico, ficaram ocupados com a preparação do congresso: trabalhos de campo, seleção dos roteiros, escolha dos pontos de alojamento, redação dos guias de campo a serem fornecidos aos congressistas, e outras tarefas mais.

Foram organizadas nove excursões, por diferentes regiões do país. Os guias distribuídos não eram simples roteiros: eram sínteses geográficas de toda a área visitada. Apenas no final encontravamse as indicações, dia por dia, do que seria realizado.

Felizmente os nossos esforços foram bem recompensados e todos os professores estrangeiros, que aqui vieram, não se cansaram de elogiar, encarecendo os excelentes resultados obtidos. Cabe salientar ainda que, foi o Brasil o $1^{\circ}$ país, depois da Guerra (19391945) a conceder visto de entrada a professores da então URSS, para que pudessem participar de um congresso científico.

Geosul - A senhora ajudou a organizar as excursões dirigidas pelos Profs. Ary França e Orlando Valverde, mas participou, efetivamente, só da que foi coordenada pelo Orlando Valverde?

Profa. Dora - Não só colaborei com a organização das duas como também participei de ambas. Já que toda a parte administrativa havia ficado a cargo do Conselho de Geografia, era obrigatória a presença de um geógrafo da Instituição em cada excursão, sendo ele o responsável por toda a parte burocrática da mesma. Por esse motivo, das atividades do Congresso propriamente dito, realizadas no Rio de Janeiro, eu quase nada vi. Cheguei na véspera da abertura, com um grupo, prestei as devidas contas e os necessários relatórios sobre a viagem que fizera com o Prof. Ary França e, em seguida, tive que providenciar todo o material necessário para partir, com o grupo do Prof. Orlando Valverde, no dia seguinte ao término do Congresso. 
Entrevista com Dora de Amarante Romariz.

Geosul - E dessas excursões participavam mais profissionais estrangeiros do que brasileiros?

Profa. Dora - Claro. Sendo o número de participantes limitado, em torno de vinte, a prioridade era dada aos estrangeiros, já que os brasileiros poderiam ter outras oportunidades. Nas duas em que participei, a não ser os dirigentes, todos os demais eram estrangeiros: alemães, franceses, finlandeses, etc.. doze nacionalidades!

Muitos já eram nossos amigos, outros assim se tornaram a partir dessas excursões e, ao retornarem a seus países, passaram a nos fazer convites para visitá-los ou para colaborar em algum trabalho que estivessem realizando.

Graças a esses contatos feitos em Congressos, tive a possibilidade de participar de alguns trabalhos interessantes. A um deles já me referi: o da elaboração do Mapa da Vegetação da América do Sul pela ICITV de Toulouse. Outro foi ter sido MembroCorrespondente da Comissão "Geografia e Educação", da União Geográfica Internacional (de 1964 a 1982). Como parte das atribuições dessa comissão foi elaborado um manual de "Geografia de América Latina", tendo eu supervisionado a parte referente às Guianas e ao Brasil e escrito quatro textos a esse respeito.

Fui também colaboradora da UNESCO (1963-1964) no denominado "Projeto Maior Oriente-Ocidente" para exame de livros didáticos de Geografia. Eram selecionados livros de diversos países e, depois de traduzidos para o idioma indicado pelo revisor, eram acompanhados por uma espécie de gabarito que deveria ser observado, para que houvesse uniformidade nos julgamentos. Um relatório era feito segundo essas diretrizes.

Geosul - E os dados sobre o Brasil nesses livros correspondiam à realidade?

Profa. Dora - Em vários deles os dados encontravam-se um tanto atrasados. É preciso compreender porém que, naquela época, não era fácil para professores de países distantes, a obtenção de dados atualizados sobre o nosso país! 
Geosul - Na AGB, como foi a sua convivência com o Prof. Peluso?

Profa. Dora - A melhor possível. Afora alguns contatos rápidos durante a passagem por Florianópolis, quando estávamos em trabalhos de campo no sul, foi apenas depois do Congresso de Washington, do qual ambos fizemos parte como membros da delegação brasileira (e também representantes da AGB) que passamos a ter uma comunicação mais freqüente. Ele participou dos congressos da AGB em Ribeirão Preto e no Rio de Janeiro. Neste, realizado em 1965, foi eleito Presidente da AGB. Organizou, então a reunião seguinte (1966) em Blumenau, sendo extremamente bem sucedido.

Tenho conhecimento de que Peluso havia participado, como engenheiro, da Campanha das Coordenadas, efetuada pela Divisão de Geodésia do IBGE, responsabilizando-se pela determinação das coordenadas do Estado de Santa Catarina. Nessa época, entretanto, ainda eu não o conhecia.

Geosul - E essa Campanha das Coordenadas, quando foi?

Profa. Dora - Foi logo no início das atividades da Divisão de Geodésia do IBGE, na década de 40. Não sei a data certa.

Geosul - O que a gente vê de livros sobre a vegetação brasileira é, principalmente, da década de 70 , como o seu livro. O que existe de mais recente é o mapa de 1991 e a "Classificação da vegetação brasileira, adaptada a um sistema universal", que é também de 1991, e nada mais. Eu pergunto para a senhora, por que acabou?

Profa. Dora - Éramos um grupo muito pequeno, que mais reduzido ficou quando alguns se aposentaram. Não tendo havido a necessária renovação, a tendência era essa mesma, parar.

O meu próprio livro, escrevi depois de aposentada. Inspirei-me numa obra francesa na qual aparece a frase: "aprender primeiro vendo e depois lendo". Tendo em vista que o nosso professor tem dificuldades para adquirir publicações, procurei reunir texto, mapas 
Entrevista com Dora de Amarante Romariz.

e ilustrações numa só obra. Elaborei o texto e depois selecionei as necessárias fotografias para ilustrá-lo. Não consiste, assim, a obra numa simples coleção de fotografias comentadas. O trabalho foi apresentado em pranchas para que, à semelhança com o que ocorre na obra francesa, pudesse ser utilizado como material didático. De acordo com o assunto que estiver sendo estudado, o professor apresenta as respectivas pranchas, e pede para que os alunos, observando-as, indiquem, com suas próprias palavras, as principais características dos tipos de vegetação nelas representados.

A $1^{\text {a }}$ edição foi publicada pelo IBGE. A $2^{\mathrm{a}}$, porém, não tendo eu concordado com a proposta que me fizeram de publicá-lo sob a forma de livro comum, e não mais em pranchas, já que isso não atenderia à finalidade para a qual fora elaborado, decidi editá-lo por minha conta.

Geosul - E de que ano são essas edições?

Profa. Dora - A primeira foi lançada no Congresso da AGB, em Belém, no ano de 1974. A segunda no Congresso da Sociedade Botânica do Brasil, em Nova Friburgo (RJ) no ano de 1996.

Geosul - Professora, nenhum geógrafo, biólogo ou botânico que falar sobre vegetação pode esquecer o seu nome!

Profa. Dora - Muito obrigada, mas posso lhes garantir que nem sempre isso acontece!

Geosul - E nesta sua preocupação em sistematizar as informações sobre a vegetação brasileira, procurou ressaltar as contribuições de Humboldt e Saint Hilaire. Comente um pouco esta sua experiência. Profa. Dora - Muito simples, porque Humboldt foi o primeiro no mundo a escrever sobre fitogeografia. Ele já tinha este conceito de que a natureza é uma só e que só dá para entendê-la quando é estudada em seu conjunto. O mesmo dizia o Prof. Gaussen: "a vegetação engloba tudo, e tudo explica". Também não deixa de ser um pouco de exagero, não é? Para a parte física, porém, é claro que 
Entrevista com Dora de Amarante Romariz.

tanto clima, quanto relevo e solo acham-se intimamente ligados à vegetação.

Como dizia, Humboldt foi o primeiro a salientar todo esse relacionamento. Durante sua viagem aos Andes, embora muitas vezes dormindo ao relento, e alimentando-se precariamente, escreveu o $1^{\circ}$ trabalho sobre fitogeografia. Intitulou-o: "Éssai sur la Géographie des Plantes". Terminou de escrevê-lo ao chegar a Guaiaquil (1803) e publicou-o pouco depois de regressar à França, dois anos após. Humboldt foi, também, quem começou a utilizar-se de "isolinhas" e "cortes" em seus trabalhos.

Humboldt nunca viajou pelo Brasil. O mais próximo que esteve de nossas fronteiras foi, quando ao chegar à Venezuela, em 1799 , ocupou-se com a determinação das coordenadas do canal do Cassiquiare, que liga as bacias do Amazonas e do Orenoco. Chegou, portanto, apenas a um sub-afluente do rio Negro, dentro ainda da Venezuela. Nem poderia ser de outra forma, pois viajava trazendo uma carta de recomendação do rei da Espanha. Se entrasse no Brasil, seria preso!

É interessante salientar que, comparando-se os valores obtidos para essas coordenadas, com os que são atualmente aceitos, os mesmos divergem apenas em um grau de longitude. Isso apesar das diferenças existentes entre os instrumentos da época e os atuais.

$\mathrm{Na}$ América do Sul foi também o $1^{\circ}$ a estudar as savanas da Venezuela; os páramos, nas áreas mais altas dos Andes e a corrente marinha que percorre a costa do Peru (que hoje tem o seu nome). Além dessas pesquisas na América do Sul trabalhou ainda, embora mais rapidamente, em Cuba, no México e nos Estados Unidos.

Convidada pelo Prof. Ronaldo Wasum, da Universidade de Caxias do Sul para participar de uma semana em homenagem a Humboldt, coube-me falar sobre "Humboldt e a Fitogeografia". Outros aspectos de sua obra foram também analisados, como as valiosas contribuições aos estudos da botânica e da geografia. Tendo em vista que não são muitos os trabalhos sobre Humboldt, acessíveis aos nossos estudiosos, decidi publicar a palestra. Como tive a oportunidade de visitar algumas das áreas que haviam sido 
percorridas por ele, utilizei algumas fotografias que aí havia tirado para ilustrar a palestra.

Vários foram os pesquisadores e viajantes que foram influenciados pelas idéias de Humboldt, entre eles Auguste de Saint-Hilaire. A semelhança de Humboldt não se limitava a observar a parte botânica, sua especialidade, mas fazia um estudo de todos os relacionamentos com o solo, exposição, relevo, etc... das plantas que colhia. Fazia observações, também, quanto aos animais da área em estudo. Tendo assim procedido nos seis anos que viajou pelo Brasil (1816-1822) pode ser considerado como tendo sido o nosso $1^{\circ}$ biogeógrafo!

No Congresso de Botânica de Ouro Preto (em 1986) houve um Simpósio sobre a vegetação de Minas Gerais, e dele fui convidada a participar. Apresentei, então, o trabalho "Viagens de SaintHilaire a Minas Gerais (sua contribuição para o estudo da vegetação)". Embora ele tenha viajado por diversos estados do Brasil, foi em Minas Gerais que ele mais trabalhou. Essa palestra foi, também, por mim publicada.

Achando-se as duas palestras, tanto a de Humboldt quanto a referente a Saint-Hilaire, praticamente esgotadas, penso colocar um resumo das mesmas, como anexos, em outro trabalho que estou pretendendo realizar.

Geosul - Fale um pouco sobre esse novo trabalho. Quando sai?

Profa. Dora - Nem Deus sabe, pois ainda nem totalmente redigido está. Mais uma vez, inspirei-me numa obra francesa (pertencente à coleção "Lês Encyclopédies du Savoir Moderne-L'Homme et son environnement"). Escolhidos alguns temas, os mesmos são desenvolvidos. No decorrer desse trabalho, alguns termos são assinalados e transformados em verbetes. Posteriormente tudo é colocado em ordem alfabética, tornando-se fácil a consulta por qualquer interessado, pois funcionará como um dicionário. No meu caso, estou selecionando para temas alguns dos assuntos tratados em meus cursos, e para os quais há uma certa dificuldade em conseguir dados. Depois, o procedimento é o mesmo: alguns 
Entrevista com Dora de Amarante Romariz.

termos que dependem de maiores explicações são transformados em verbetes e tudo colocado em ordem alfabética.

Geosul - Tem previsão de lançamento?

Profa. Dora - Nenhuma! Nem totalmente redigido está. Só posso informar o título: "Biogeografia - Temas e Conceitos".

Geosul - A senhora teve a oportunidade de trabalhar com o Prof. Aroldo de Azevedo para a Enciclopédia Barsa.

Profa. Dora - Sim. Ao ser incumbido de coordenar a parte da Geografia da Enciclopédia Barsa, o Prof. Aroldo convidou-me para redigir os verbetes referentes à Biogeografia.

Anteriormente já havia participado de outro trabalho dirigido por ele. Escrevi o capítulo sobre a vegetação no livro "Brasil: a Terra e o Homem (Volume I: As Bases Físicas)". Publicado pela Cia. Editora Nacional. Dele saíram duas edições: a $1^{\text {a }}$ em 1964, logo seguida pela $2^{\mathrm{a}}$, em 1968 , e hoje totalmente esgotada. Foi um trabalho muito útil, pois reunia sínteses relativas aos diferentes aspectos da geografia física do Brasil.

Uma outra experiência minha no tocante às Enciclopédias foi com o Círculo de Leitores de Lisboa, Portugal. Ao editar a Enciclopédia Larousse Ilustrada, convidaram-me a redigir um texto sobre o Brasil e outros menores sobre cada estado brasileiro. A primeira participação foi em 1997, tendo sido efetuada a necessária revisão para a nova edição agora, em 2007.

Geosul - A sua grande experiência é a contribuição que deu através do IBGE. E no IBGE a senhora, com certeza, conheceu grandes nomes, como a Lysia, o Nilo!

Profa. Dora - Não foi bem assim: Lysia foi minha colega na Faculdade de Filosofia e, como a maioria da minha turma foi ser geógrafa do IBGE. Alguns colegas, entretanto, vieram de outras procedências: o Nilo fez o curso na Faculdade Católica (PUC); o Walter Egler (pai do Cláudio) veio da Escola de Agronomia, etc. Mas não foram muitos! 
Geosul - E como se deu a sua aproximação com o Prof. Carlos Augusto? Por que ele diz que a senhora é a fada madrinha dele?

Profa. Dora - Quando o Conselho Nacional de Geografia teve de fazer o estudo das áreas, entre as quais seria escolhida aquela onde seria instalada a Capital do Brasil, mesmo reunindo todos os seus geógrafos, não havia o número suficiente para completar os grupos de trabalho. Além de convidar alguns técnicos de outras Instituições, ficou decidido, também, que seriam incluídos alguns alunos do Curso de Geografia da Faculdade, para a função de auxiliares. Isso era possível, já que no mês de Julho (primeiro mês de nossos trabalhos) eles estariam em férias. Terminadas essas, regressariam ao Rio de Janeiro, e os grupos seriam reestruturados, com um número menor de participantes. No fim de Julho, entretanto, o Prof. Ruellan, que havia gostado muito do trabalho do Carlos Augusto, "fez-lhe uma falseta", disse-lhe que podia ficar até o fim da excursão e voltar conosco. Já teria falado com o chefe de onde ele trabalhava e fora tudo aprovado! (Esclarecendo: o Carlos Augusto, para poder se manter e fazer a Faculdade, tinha um emprego. Para participar da excursão pedira suas férias anuais coincidindo com as da Faculdade). Regressando ao Rio, ao se apresentar em seu local de trabalho, teve a informação de que havia sido despedido, pois não se apresentara após o término das férias. Desesperado, foi me procurar no Conselho de Geografia! Procurando resolver a situação fui falar com o Dr. Cristóvão Leite de Castro, Secretário-Geral da Instituição, pedindo sua ajuda. Ele, sempre muito compreensivo e simpático, deu risada com a "astúcia" do Professor e disse-me: "manda cá o Carlos Augusto: há muitas mulheres nesta casa; estávamos mesmo precisando de mais rapazes". E assim, ainda bem no início de seu curso da Faculdade, entrou para o $\mathrm{CNG}$, graças à minha interferência. 
Entrevista com Dora de Amarante Romariz.

Geosul - E como era um grupo grande de mulheres, os trabalhos de campo deveriam ser muito difíceis...

Profa. Dora - Bem, nem sempre foi fácil mas, é claro, sempre tivemos vários colegas no grupo. Tudo era resolvido com muita esportividade e companheirismo. Tornamo-nos uma grande família! $\mathrm{Na}$ excursão ao Planalto Central ficamos sempre em barracas. Estas eram grandes e comportavam até dez pessoas. Havia uma divisão no meio e uma porta de cada lado: por uma entravam os rapazes e por outras as moças. Em outros abrigos (em geral nos caminhões) ficava o pessoal que nos acompanhava: motoristas, cozinheiro, porta-balisas e auxiliares. Montávamos e desmontávamos o acampamento todos os dias, à medida que os trabalhos avançavam. Um tanto cansativo, convenhamos!

Geosul - Eu acho que o filho do Prof. Ruellan esteve recentemente no Brasil, tentando resolver o assunto, não foi?

Profa. Dora - Sim, mas não tinha condições para isso. Ele era muito jovem quando, como auxiliar, participou dos trabalhos. Não tinha, porém, nenhuma noção da estrutura e organização dos mesmos.

Recentemente (2004) fui convidada pelo Departamento de Geografia da Universidade de Brasília para fazer uma palestra sobre o assunto. Expliquei, então, porque a comissão instituída pelo IBGE, havia se dividido em dois grupos: o maior, encarregado dos levantamentos e estudos de detalhes (o nosso), chefiado pelo Prof. Ruellan (que era contratado pelo CNG) e o outro, bem menor, que se ocupou com as observações de conjunto, chefiado pelo Dr. Fabio Guimarães, com a acessória técnica do Prof. Leo Waibel, ambos igualmente do CNG. No final, os relatórios dos dois grupos foram fundidos e a Comissão apresentou um só relatório, englobando os resultados finais dos trabalhos.

Geosul - Gostaria que a senhora falasse um pouco mais desse trabalho para a escolha do sítio para a Nova Capital e se o trabalho foi respeitado em suas conclusões. 
Entrevista com Dora de Amarante Romariz.

Profa. Dora - Eram oito as áreas que nos foram apresentadas para o estudo: quatro no Triângulo Mineiro e quatro em Goiás. O trabalho foi feito e o relatório apresentado, como já vimos. A Comissão Central, que havia sido nomeada pelo Governo, tendo em vista que eram duas as áreas indicadas: o antigo Retângulo Cruls e a nova, mencionada, decidiu que a escolha seria feita por votação. Terminada esta venceu a área do Retângulo, por sete votos a cinco.

Saiu vencedor, portanto, o grupo cujo propósito era o de levar a Capital para um ponto bem interior, o mais distante possível do litoral, fomentando assim a ocupação de novas áreas. O outro grupo, achava que a mudança da Capital deveria ser feita o mais rapidamente possível e, por isso, precisava que fosse escolhida uma região que já tivesse a infra-estrutura necessária para acolher a Capital dispondo, ainda, de boas comunicações com o Rio de Janeiro.

Como se vê, os resultados dos relatórios saíram perdendo na decisão final.

Geosul - E qual foi a área que vocês escolheram?

Profa. Dora - Foi uma área do oeste do Triângulo Mineiro, nos limites com o sul de Goiás. No relatório foi indicada como Área C - Uberlândia-Tupaciguara, por atender a mesma, plenamente, aos objetivos colimados pelo grupo de trabalho.

É curioso ressaltar, entretanto, que nos mapas antigos do Brasil, já se achava indicado um retângulo onde se lia: "Área do Futuro Distrito Federal" e que corresponde, aproximadamente, à que é ocupada pela do atual. Além disso existe, em Planaltina, um obelisco indicando o local da Nova Capital.

Geosul - E esse retângulo está no mapa desde quando?

Profa. Dora - Acredito que desde o início do século vinte, já que a expedição Cruls foi realizada em 1892.

Antes de terminarmos de falar do assunto referente a esses estudos no Planalto Central eu gostaria, por uma questão de justiça, de 
assinalar o quanto o nosso grupo foi ajudado pelo Dr. Bernardo Sayão, então diretor da Colônia Agrícola Nacional de Goiás (CANGO), no período em que estivemos nas proximidades da mesma. Mais tarde foi ele o grande responsável pela abertura da estrada Belém-Brasília. Infelizmente não a pode ver terminada: faleceu quando foi atingido por uma árvore que caiu sobre a barraca em que trabalhava. Em sua homenagem, essa estrada chama-se "Rodovia Bernardo Sayão".

Geosul - A senhora contribuiu também com algumas universidades brasileiras. Conte um pouco sobre esta experiência.

Profa. Dora - A minha experiência mais efetiva foi com a Universidade de Brasília. Alguns anos depois de aposentada fui convidada para lá trabalhar. Em virtude, porém, de compromissos anteriormente assumidos, só me foi possível atuar como ProfessorVisitante por um semestre: o $1^{\circ}$ de 1978. Em outras Universidades, em períodos mais curtos, ministrei cursos de caráter intensivo, sobretudo para alunos de Botânica, tanto na Graduação (na FURB, em Blumenau) quanto na Pós-Graduação: na Federal do Rio de Janeiro, em Pernambuco, no Rio Grande do Sul, em Mato Grosso do Sul, entre outras.

Geosul - Por que a senhora não quis se engajar em uma universidade?

Profa. Dora - Por ser geógrafa do CNG não me seria possível lecionar numa universidade. Pesquisar era a nossa tarefa principal e assim, pode-se dizer que, ganhava para estudar! Viajava-se muito naquele tempo, pois muita cousa estava por ser conhecida e estudada. Ao mesmo tempo, estava formando um bom cabedal para que, mais tarde, depois de aposentada, como estou fazendo agora, me fosse possível oferecer aos alunos que assistem meus cursos, um material muito mais interessante, grande parte das vezes fruto de observações pessoais. Considerei ainda que, sendo poucos os professores que se dedicam à fitogeografia, achei que teria aí um bom campo de trabalho, como realmente aconteceu. 
Entrevista com Dora de Amarante Romariz.

Essa circunstância também me havia sido assinalada pelo Prof. Ruellan, o $1^{\circ}$ a me incentivar a assumir essa especialização, e isso desde o tempo da faculdade. Mais tarde, fiz o curso com o Prof. Dansereau, como já disse. Tive a oportunidade de trabalhar também com o Prof. Kurt Hueck, quando ele esteve no CNG. Nessa Instituição tivemos a possibilidade de fazer cursos, estágios, etc. o que nos trouxe grandes benefícios em nossa carreira.

Voltando, porém, à pergunta: preferi não me fixar numa só universidade pois sou frequentemente convidada para dar cursos intensivos e, se pertencesse a uma determinada instituição não poderia aceitar esses convites!

Geosul - Gostaríamos que a senhora falasse um pouco da sua assessoria para a criação ou manutenção de áreas verdes.

Profa. Dora - Em São Paulo, na década de 70, fui convidada pela EMPLASA para estabelecer os padrões que caracterizariam os tipos de vegetação, cuja preservação deveria ser exigida, com a finalidade de manutenção das áreas verdes existentes nos lotes, por ocasião da concessão dos mesmos. Ao realizar o trabalho pedi para ser acompanhada por um grupo de pesquisadores da Instituição, assegurando, assim, o treinamento de seus próprios funcionários. Foi um grupo muito bom e bem interessado. Ao que eu saiba, continuam a aplicar o que treinaram comigo.

Geosul - Teve uma experiência parecida em Salvador?

Profa. Dora - Não, em Salvador o trabalho foi bem diferente. Há na cidade um sério problema: grandes avenidas foram abertas em fundos de vales, sendo as encostas dos mesmos enormemente devastadas, ocasionando grandes problemas por ocasião das chuvas.

Observando algumas dessas encostas verifiquei que, em algumas, ainda restava um pouco da vegetação natural. Apresentei, então, a sugestão que me pareceu mais adequada. Seriam feitos levantamentos e as necessárias coletas das plantas que compunham esse tipo de vegetação ainda existente. Após a indispensável 
Entrevista com Dora de Amarante Romariz.

identificação, seriam as mesmas utilizadas no repovoamento das encostas prejudicadas. Sendo as espécies daí originadas, certamente se desenvolveriam bem, passando a revestir novamente as encostas. Para a identificação desse material coletado era preciso, porém, esperar alguns meses, já que cada planta tem o seu período de floração e, sem esta a identificação botânica é muito difícil. Parece-me que o fato de ter que esperar para que isso ocorresse não agradou, e a minha sugestão não foi aceita.

Geosul - Mais ou menos nesta linha, como é que a senhora avalia a política nacional no tocante às unidades de conservação?

Profa. Dora - No papel, estamos relativamente bem servidos. Há um bom número de unidades de conservação, dos mais variados tipos. $\mathrm{Na}$ realidade, porém, os resultados não são dos mais satisfatórios. O Brasil, sendo um país muito grande, apresenta grandes dificuldades para que as exigências que o problema requer possam ser cumpridas. Também, o conceito de conservação, hoje, não é mais o de intocabilidade, mas sim o de uso racional. Talvez isso até dificulte um pouco mais a obtenção dos resultados desejados, não é mesmo?

Geosul - Como a senhora vê a geografia brasileira hoje quando comparada com a do seu tempo?

Profa. Dora - Não há possibilidade de comparação pois, até mesmo as conceituações básicas, referentes à geografia, parece que foram modificadas. O geógrafo passou a fazer, como eu vi na reunião da $\mathrm{AGB}$, no Acre, mais sociologia do que geografia. Então, como não estava capacitado para isso, se descredenciou: passou a não fazer direito, nem uma cousa nem outra.O que eu vi no Acre, de geografia foi quase nada e, o que era assim designado, voltavase mais para a sociologia ou, mesmo, para a política. Essa modificação de conceitos foi aliás, o principal motivo de eu ter me distanciado da AGB, já que a minha concepção de geografia é bastante diferente! 
Entrevista com Dora de Amarante Romariz.

Também no IBGE, com a aposentadoria da maior parte dos geógrafos que aí trabalhavam, e da não admissão de novos elementos capacitados para esses estudos, pode-se dizer que a geografia acabou. Isso se refletiu, também, no setor de publicações, pois deixaram de circular o Boletim Geográfico e a Revista Brasileira de Geografia, os principais periódicos que existiam no Brasil nessa especialidade. Até hoje são muito procurados pelos excelentes trabalhos neles contidos.

Geosul - Na Revista Brasileira de Geografia existia uma secção que eu acho muito interessante: aquela que tratava dos Tipos e Aspectos do Brasil.

Profa. Dora - Sim. Em cada número da Revista existia essa secção, sendo responsável por ela o nosso excelente desenhista Percy Lau. Foi ele o executor de todos os desenhos até 1967, quando se aposentou. A secção, porém, continuou a existir, embora o tipo de traço apresentado pelo desenho fosse bem diferente.

De início a seç̧ão contava com dois "Tipos e Aspectos" por número; depois foram reduzidos a apenas um, até que, se não me engano, a partir do Ano 45 da Revista, deixou de existir.

De tempos em tempos era publicada uma coletânea, sempre vendida com muito sucesso. A 10a e última, foi editada em 1975.

Por ocasião do XVIII Congresso Internacional de Geografia, realizado no Rio de Janeiro em 1956, uma coletânea especial foi traduzida para o francês e para o inglês: foi distribuída a todos os congressistas, tendo sido muito elogiada.

Geosul - Gostaríamos que comentasse um pouco sobre a sua experiência com André Libault.

Profa. Dora - Quando o Prof. Ary França estava na chefia do Departamento de Geografia da Fac. de Filosofia da USP, sentindo a falta que fazia a cartografia no currículo desse Departamento, solicitou ao Prof. André Libault, Diretor do Instituto de Cartografia de Paris, a indicação de um professor que para aqui viesse, a fim de preencher essa lacuna. A resposta veio rápida e causou-nos grande 
Entrevista com Dora de Amarante Romariz.

alegria: em lugar de indicar alguém, ele próprio se candidatou a isso. Aqui chegando em 1962, permaneceu no Departamento até 1973.

Como, de minha parte, também sentia falta dessa matéria pois, de forma sistemática nunca havia estudado cartografia, decidi-me a fazer a minha pós-graduação sob a direção dele. Até então a pósgraduação não havia entrado em minhas cogitações. O principal motivo é que no $\mathrm{CNG}$, por viajarmos muito, era inviável engajarme num projeto que requeria vários anos para o seu término. Ao aproximar-se a época de minha aposentadoria, entretanto, por saber que nos cursos de pós-graduação de botânica havia a fitogeografia, resolvi aproveitar a presença de tão ilustre mestre, e adicionar mais uma credencial às que já possuía.

O sistema que vigorava na época era diferente. A pós-graduação durava 4 anos e, para a obtenção dos créditos necessários, era exigida a presença em outros cursos. Um deles, escolhido por mim, foi $\mathrm{o}$ de pedologia, indispensável para os trabalhos de fitogeografia. Não havia a exigência de apresentação de tese. Esta só era obrigatória quando o professor fazia concurso para assumir um posto na Universidade. Ao terminar o curso, tendo preenchido todos os requisitos do mesmo, recebi o diploma de pós-graduada em 1969.

Pouco depois, porém, mudou o regime e, inexplicavelmente, as exigências que passaram a ser feitas foram consideradas, também, como sendo válidas para os cursos anteriormente feitos. Para todos os pós-graduandos que não tinham tese, por exemplo, o curso passou a ser considerado apenas de "aperfeiçoamento" e não mais de pós-graduação. Injustiça essa que prejudicou muita gente! Mas, é bem verdadeiro o que diz o velho ditado: "Santo de casa não faz milagre". Quando fui convidada pela Universidade de Brasília para lecionar, o titulo que mais pesou, por ocasião do meu credenciamento foi esse! Graças a ele fui contratada na categoria de Professor-Titular. Enquanto para a USP, onde fiz o curso, o mesmo não passa na categoria de "aperfeiçoamento", menor valor, portanto! 
Entrevista com Dora de Amarante Romariz.

O Prof. André Libault, além dos cursos que aqui ministrou, deixounos um outro legado, igualmente importante. O livro que aqui escreveu, intitulado "Geocartografia", publicado em 1975, pela Cia. Editora Nacional em conjunto com a Editora da Universidade de São Paulo.

Geosul - E com a turma nova da geografia, dos anos 1970 e 1980, teve contato? Com o Milton Santos e outros?

Profa. Dora - O meu contato com o Milton Santos não se deu em 1970 mas em 1950, quando, pela primeira vez, ele participou de uma reunião da AGB, em Belo Horizonte. Foi também na AGB que o Aziz Ab'Saber começou a se projetar na Geografia, ao participar da Assembléia de Goiânia, em 1948. Ambos estavam em inicio de carreira e, é claro, quase nada haviam produzido até então. Não só para esses dois, como para muitos outros, a AGB foi uma verdadeira escola. Pelo tipo de reuniões que promovia, com a realização de trabalhos de campo e confecção dos respectivos relatórios, propiciava a muitos estudiosos a grande oportunidade da prática de trabalhos de campo. Esse sistema de reuniões era elogiado até no estrangeiro e, por varias vezes, contamos com a participação de colegas da Argentina e do Uruguai. Com o tempo, entretanto, tendo aumentado muito o número de participantes, esse tipo de trabalho não foi mais possível!

Geosul - Com toda a sua experiência de AGB, como vê o encontro realizado no Acre?

Profa. Dora - Resolvi participar do Congresso no Acre, após muitos anos de afastamento dessas reuniões da AGB, por dois motivos: um era a oportunidade de visitar um dos únicos Estados ao qual nunca havia ido e, outro, este diretamente ligado à AGB, como vou explicar.

Na reforma dos Estatutos da AGB, realizada em São Paulo, em 1945, foram criadas as Secções Regionais, estabelecendo-se logo a de São Paulo. A do Rio de Janeiro foi criada logo a seguir. Com a finalidade de promover o congraçamento entre ambas, ficou 
Entrevista com Dora de Amarante Romariz.

decidido que a $1^{\mathrm{a}}$ reunião seria em Lorena, cidade do vale do Paraíba, a meio caminho, portanto de ambas. Isto em janeiro de 1946.

Tendo eu participado dessa reunião, quis ter o prazer de, sessenta anos depois, ter a possibilidade de estar presente nesta e poder constatar o quanto aquela semente que havíamos plantado, havia se desenvolvido. Os vinte e poucos participantes de Lorena, são milhares hoje em Rio Branco. As duas Secções Regionais multiplicaram-se, acham-se espalhadas por todo o Brasil, e continuam a trabalhar. Se o tipo de trabalho mudou - não importa! $O$ que vale é que a AGB continua viva e atuante! Fui homenageada, recebida com muito carinho: isso me deixou muito feliz. Agradeço, sinceramente, a todos que lá estiveram.

Geosul - Agradecemos muito à Professora Dora por ter vindo a Florianópolis e nos conceder esta entrevista. 